\title{
Hercules, Cacus, and the Poetics of Drains in Aeneid 8 and Propertius 4.9
}

\author{
Del A. Maticic
}

Water is a central element in Book 8 of the Aeneid, which opens at the mouth of the Tiber, where the Trojans encounter Tiberinus, and ends with the Shield of Aeneas that is encircled by rivers and centered on the Mediterranean Sea, where the Battle of Actium was to take place. It thus comes as a surprise that Evander's account of the battle between Hercules and Cacus (Verg. Aen. 8.19o261) is comparatively waterless, and the hero instead fights the fiery, threeheaded son of Vulcan whom he finds in a volcano-like cavern beneath the earth. ${ }^{1}$ The absence of water here is especially surprising, since Hercules, as one of what Nicholas Purcell has called "the heroes of drainage", was often credited with transformations in the Greek hydrological landscape through the draining of lakes, the re-direction of rivers, and the excavation of subterranean channels. ${ }^{2}$ One may see this nowhere more clearly than in Propertius' account of the same Herculean episode in Elegy 4.9, which takes Vergil's account as its most important interlocutor but focuses in particular on the flooded valleys and springs of the primeval landscape. ${ }^{3}$ As this chapter argues, however, Vergil does in fact deploy Hercules as Master of Waters in Aeneid 8, but does so by

1 In the episode, the Tiber River appears only once, in what seems to be an aside. See Verg. Aen. 8.236-240. On water in Verg. Aen. 8, see esp. D. Quint, 'Culture and nature in Book 8 of the Aeneid', MD 75 (2015), 9-47.

2 N. Purcell, 'Rome and the management of water: Environment, culture, and power', in G. Shipley and J. Salmon (eds.), Human Landscapes in Classical Antiquity: Environment and Culture (London 1996), 180-212; 205. For discussions of Heracles' role as water-manager in Greek myth, see C. Salowey, 'Herakles and the waterworks: Mycenaean dams, classical fountains, Roman aqueducts', in K.A. Sheedy (ed.), Archaeology in the Peloponnese: New Excavations and Research (Oxford 1994), 77-95; T. Châtelain, La Grèce antique et ses marais: Perception des milieu palustres chez les Anciens ( $\mathrm{PhD}$ thesis, Sorbonne 2007); K. Walsh, The Archaeology of Mediterranean Landscapes (Cambridge 2014), 108. For his role as "water master" in Italic myth, cf. J. Bayet, Les origines de l'Hercule romain (Paris 1926), 203-236 and V. Martinez, Etrusco-Italic Herclé: A Study in the Formation of Image, Cult, and Regional Identity (unpublished $\mathrm{PhD}$ thesis, Urbana-Champaign 2009).

3 For other Augustan-era versions of the story, see Liv. 1.7.5-15; D.H. 1.39; Ov. fast. 1.543-586; 643-652. See also Macr. 1.12.27. On Greek origins of the myth, see D. Sutton, 'The Greek origins of the Cacus myth', CQ 27 (1977), 391-393. 
focusing not on water but on drainage works. By alluding to the hydrological infrastructure of contemporary Rome, on the one hand, and to Hercules' activities as Master of Waters in Greece on the other, both Vergil and Propertius allegorize not only Rome's cosmic and terrestrial power, but also its subterranean, hydraulic influence in the world, its relationship to the Greek past, and the excesses of its thirst.

Scholarship has shown that the episode is an important device through which the poets foreshadow historical events and explain the transformation of the physical and religious landscape of the city. ${ }^{4}$ In the Aeneid especially, scholars interpret the fight as a prefiguration of the conflict between Aeneas and Turnus that in turn anticipates the battle of Actium. ${ }^{5}$ There is also considerable interest in both versions of the episode as etiologies of the important Roman cult of the Ara Maxima. ${ }^{6}$ Finally, more recent readings have shown particular interest in Hercules' associations with transformations and, in

4 For commentaries on Verg. Aen. 8, see L.M. Fratantuono and R.A. Smith, Virgil, Aeneid 8 (Leiden 2018); K.W. Gransden, Aeneid Book VIII (Cambridge 1976); P.T. Eden, A Commentary on Virgil: Aeneid VIII (Leiden 1975); F. Klingner, Virgil: Bucolica, Georgica, Aeneis (Stuttgart 1967). An especially thorough commentary on Propertius Book 4 is P. Fedeli, I. Ciccarelli and R. Dimundo, Properzio. Elegie, libro IV I-II (Nordhausen 2015). See also G. Hutchinson (ed.), Propertius Elegies Book IV (Cambridge 2006). One concern in scholarship I do not address below is the generic associations of the Propertian Hercules. On this question, see P. Pinotti, 'Propertius IV 9: Alexandrianism and allusion', in E. Greene and T.S. Welch (eds.), Oxford Readings in Classical Studies: Propertius (Oxford 2012), 116-137; J. Fabre-Serris, 'Explorations génériques au livre IV de Properce. Des voix nouvelles dans l'élégie: quelques réflexions sur les poèmes 7 et 9', in D. van Mal-Maeder, A. Burnier and L. Núñez (eds.) Jeux de voix. Énonciation intertextualité dans la littérature antique (Bern 2009), 157-173; S. Lindheim, 'Hercules cross-dressed, Hercules undressed: unmasking the construction of the Propertian “amator" in Elegy 4.9', AJP 119 (1998), 43-66; W.S. Anderson, 'Hercules Exclusus: Prop. IV.9', $A J P 85$ (1964), 1-12. Many of the discussions about epic and elegy in 4.9 stem from Anderson's important article on the paraclausithyron conceit (i.e., an elegiac trope in which a man is stuck outside his lover's door weeping and begging entry).

5 Fratantuono, Smith 2018, op. cit. (n. 4), 16. See esp. Quint 2015, op. cit. (n. 1); L. Morgan, 'Assimilation and civil war: Hercules and Cacus', in H.-P. Stahl (ed.), Vergil's Aeneid:Augustan Epic and Political Context (Swansea 1998), 175-197; G.K. Galinsky, 'The Hercules-Cacus episode in Aeneid VIII', AJP 87 (1966), 18-51; V. Pöschl, Die Dichtkunst Virgils: Bild und Symbol in der Aeneis (Vienna 1950), 276. On Propertius 4.9 and Augustus, see M. Berry, 'Political poetics: the Bona Dea episode in Propertius 4.9', Latomus 70 (2-11), 391-404; D. Spencer, 'Propertius, Hercules, and the dynamic of Roman mythic space', Arethusa 34 (2001), 259-284; U. Huttner, 'Hercules und Augustus', Chiron 27 (1997), 369-391. Relatedly, see P. Hardie, Virgil's Aeneid: Cosmos and Imperium (Oxford 1986), 215-219 on Hercules as a champion of Roman religion contrasted with the Lucretian figures of Hercules and Epicurus.

6 Pinotti 2012, op. cit. (n. 4) provides a comprehensive account of the complex etiologizing in 4.9 . 
particular, augmentations of the natural and built environment of Rome. ${ }^{7}$ However, as this chapter will argue, an analysis of the drains in the passage reveals a more complex symbolism. On the one hand, allusions to subterranean channels figure continuities and connections between Augustan Rome and the distant Greek and Italic past. On the other hand, the drains problematize the discontinuity and disruption that attends the disappearance of water beneath the earth. By drawing attention not only to drains themselves but also to desiccated bodies and landscapes, both poets use Hercules and Cacus to expose both the symbolic power of Roman waterworks and also the anxieties about the city's increasingly excessive consumption of water under Augustus and Agrippa.

In what follows, this chapter shall first discuss how the two poems figure drainage through imagery and intertextuality and shall then interpret the function of this poetic drainage in the hydrological environment of early Augustan Rome. Let us first consider the evidence in the poems themselves. In both accounts, the activity of Hercules culminates with bodies and landscapes drying out. In the Aeneid, Hercules throttles Cacus' neck and drains his throat of blood (siccum sanguine guttur, 8.261). In Propertius' elegy, Hercules' swift dispatching of the monster culminates with him noticing that the exertion left his mouth parched (sicco torret sitis ora palato, 4.9.21) and his beard dry (in siccam congesta puluere barbam, 4.9.31). This thirst leads him to break into the ritual enclosure to drink dry the fountain in the shrine of the Bona Dea (at postquam exhausto iam flumine uicerit aestum, / ponit uix siccis tristia iura labris ... 4.9.63-64), an act which leads to his founding of the Ara Maxima cult as an act of retribution against the priestesses who denied him a drink. ${ }^{8}$ These parallel constructions invite a reading of these lines together, though scholars have not explained why, in both encounters, the fight with Cacus ends with Hercules acting as an agent of drainage and desiccation.

This imagery is no less present earlier in the Vergilian account. After running back and forth several times across the Aventine in search of his adversary, Hercules rips a hole in the hill, exposing Cacus' cavernous lair (Aen. 8.241-246):

7 On Verg. Aen. 8, see M. Loar, 'Hercules, Mummius, and the Roman triumph in Aeneid 8', CP 112 (2017), 45-62; and L. Crofton-Sleigh, 'The mythical landscapers of Augustan Rome', in J. McInerney and I. Sluiter, (eds.), Valuing Landscape in Classical Antiquity: Natural Environment and Cultural Imagination (Brill 2016), 383-407. V. Panoussi, 'Spinning Hercules: gender, religion, and geography in Propertius 4.9', CW 109 (2015), 179-194; and Spencer 2001, op. cit. (n. 5) deal with the landscape in Prop. 4.9, though both with mythic and ideological rather than 'natural' or 'environmental' space.

8 All citations of Propertius are taken from S.J. Heyworth, Sexti Properti Elegi (Oxford 2007). 
At specus et Caci detecta apparuit ingens

regia, et umbrosae penitus patuere cauernae,

non secus ac si qua penitus ui terra dehiscens

infernas reseret sedes et regna recludat

pallida, dis inuisa, superque immane barathrum

cernatur, trepident immisso lumine Manes.

But the cave and the vast uncovered palace of Cacus appeared, and the shady caverns opened deeply, no differently than if the earth, gaping deeply on account of some force unlocks its infernal abodes and discloses the pale kingdom, abhorred by the gods, and above an immense chasm is perceived, and the ghosts are disturbed by the light let in. ${ }^{9}$

One function of this detail is further to associate Cacus with the chthonic realm and, by extension, Hercules with an Apollonian Augustus fighting against the forces of darkness, as he does later in the Actium scene on the Shield of Aeneas. ${ }^{10}$ But the passage, and the word barathrum in particular, have other connotations as well.

The relatively rare word barathrum here translated "chasm" has connotations of gluttony, excess, and the infernal, as Fratantuono and Smith note. ${ }^{11}$ Its only other appearance comes in Aen. 3.421-422, where it refers to Charybdis threatening to swallow up the ships of Aeneas. In Roman poetry, the word is used either to allude to the punishment pits of Athens, called barathra, the sewers of Rome, the underworld, or the "bottomless pit" of the human gut. ${ }^{12}$ Indeed, the image of the gaping hole in the earth full of smoke that Cacus belches out prefigures the allusion to his guttur (throat) in 361 , since it can refer either to physical drainage works or to the bodily "drain" of the digestive system. The polyvalence is captured well by Plautus in the Curculio, when a slave tells a drunk woman about to drink more wine to "pour it into the pit and drain the sewer quickly" (effunde hoc in barathrum, propere prolue cloacam, 124). In Plautus' Rudens, set in Cyrene, when the pimp Labrax muses that he might go to the shrine of Venus, his business partner Charmides snaps that he should rather jump in a hole (LAB. intro rumpam iam huc Veneris fanum. CHAR. In barathrum mavelim, 570). Viewers would perhaps have been transported

$9 \quad$ All translations unless otherwise specified are my own.

10 See, e.g., Fratantuono, Smith 2018, op. cit. (n. 4), ad loc. 245-246.

11 Fratantuono and Smith 2018, op. cit. (n. 4), ad loc. 8.245.

12 See C.J. Tuplin, 'Catullus 68', CQ 31 (1961), 113-139 for a still comprehensive survey of the evolution of the Latin barathrum. 
mentally to the shrine of Venus Cloacina in the Roman Forum. ${ }^{13}$ Horace may refer to the "abyss of the market", which gives the greedy stomach whatever it wants (barathrum ... macelli / quicquid quaesierat, ventri donabat avaro, Ep. $1.15 \cdot 31-32)$.

The word also denotes the human gut. In De Rerum Natura, Nature calls the griping old man a "bottomless pit" (baratre, 3.955) trying in vain to be satiated. Just ten lines later (3.966), the poet dismisses the afterlife by saying that no one enters into the abyss (in baratrum) or Tartarus. The embodied play on the "pit" here is a distinctly Lucretian touch, with hints of satire. These disparate images of physical and bodily drainage works are conveniently brought together in metaphorical characterizations of the drainage works of Rome. As Emily Gowers has shown, Cicero and other Roman authors anthropomorphize the city and identify the Cloaca Maxima with its digestive system. ${ }^{14}$ Several Roman myths and historical anecdotes reinforce this, and it captured most succinctly in a fragment of Varro's Menippean Satires in which he identifies the different parts of the urban corpus: "the gates are the senses, the aqueducts the veins, and the drains the intestines" (sensus portae, uenae hydragogiae, clauaca intestini, fr. 290 Astbury). ${ }^{15}$

Vergil's first-recorded interlocutor, Propertius, makes similar connections between bodies, landscape, and consumption. In his Elegy 4.9, Propertius retells the episode and focuses closely on Hercules' relationship to the waters on the future site of Rome. Propertius recounts how Hercules arrived, defeated Cacus, and established the cult of the Ara Maxima. It opens with his arrival on a once inundated site. See Prop. 4.9.1-6:

Amphitryoniades qua tempestate iuuencos egerat a stabulis, o Erythea, tuis uenit ad inuictos pecorosa Palatia montes, et statuit fessos fessus et ipse boues, qua Velabra suo stagnabant flumine quaque nauta per urbanas uelificabat aquas.

13 On the religious architecture associated with the Cloaca Maxima, see J.N. Hopkins, 'The sacred sewer: Tradition and religion in the Cloaca Maxima', in M. Bradley and K. Stow (eds.), Rome, Pollution and Propriety: Dirt, Disease and Hygiene in the Eternal City from Antiquity to Modernity (Cambridge 2012), 81-102.

14 E. Gowers, 'The anatomy of Rome from Capitol to Cloaca', JRS 85 (1995), 23-32, esp. 26-30.

15 For example, Gowers 1995, op. cit (n. 14), 26 points out Livy's (1.55.5-6) connecting of Tarquin's constructions on the Capitoline (the caput of Rome) and his excavation of the Cloaca Maxima. For other examples, see Gowers 1995, op. cit. (n. 14), 29. 
In that season when the son of Amphitryon had led his young bulls from your stables, O Erythea, he came to the unconquered hill, the Palatine packed with herds, and rested his exhausted cattle, himself exhausted, where the Velabrum used to be inundated by its own river and where the mariner spread his sails over urban waters.

After his arrival, he meets and kills Cacus within the first twenty lines of the poem. Immediately after the battle ends, the poet causes us to recall the topography the instant he defeats his foe and commands his cattle to moo in the new Forum Boarium ("sanctify the Bovine Fields with a long moo," arva ... mugitu sancite Bovaria longo, 4.9.19). Propertius writes (4.9.21-22):

\section{Dixerat, et sicco torret sitis ora palato,}

Terraque non ullas feta ministrat aquas.

[Hercules] spoke, and, with his palate dry, thirst roared through his mouth and the teeming earth did not furnish any water.

Three things are to be observed in this passage: it is now Hercules' mouth and not Cacus' that is parched; the formerly flooded landscape is now apparently dry; and these two factors are simultaneously signalled and liked through the pun on palatia in palato. Recently, Pinotti has read the effect of the transition from the lofty landscape depictions and epic heroics to a focus on Hercules' thirst as one of absurdity, which contributes to the contrast between the Propertian and Vergilian Hercules. ${ }^{16}$ The palatal pun, in this case, would merely function to draw attention to a conceit of genre and characterization. ${ }^{17}$

It would appear, however, that there is more to the joke. Some fifty lines later, after Hercules finds and is denied a drink by the Bona Dea girls, he

16 Pinotti 2012, op. cit. (n. 4), 125 .

17 H.E. Pillinger, 'Some Callimachean influences on Propertius 4.9', HSPh 73 (1969), 171-199: 186 notes as precedents for Propertius' version of the myth the Lindian sacrifice and Theiodamus story, which are "both etiological narratives that explain ritual procedure and terminology on the basis of H's notorious gluttony." Another important intertext is Apollonius Rhodius' Argonautica 4.1432-1449. D.A. Secci, 'Hercules, Cacus, and Evander's myth-making in Aeneid 8' HSPh 107 (2013), 195-227: 200 writes: "The selfishness of Hercules' motives, and the mindless violence he employs are modeled on Arg. 4.14321449. Hercules, who is described by the Hesperides nymphs as a savage robber, slays the serpent. Then, in his thirst-induced frenzy, he generates a spring by kicking a rock asunder, thus involuntarily saving his fellow Argonauts from dying of thirst." 
subsequently breaks in and drinks his fill. He then opens his mouth to rebuke the women and down dribbles another pun $(63-64):{ }^{18}$

At postquam exhausto iam flumine vicerat aestum, Ponit vix siccis tristia iura labris ...

But after he conquered the heat with the river he exhausted, he pronounces his sad decree with barely dry lips.

The striking similarities between lines 21 and 64 reinforce the verbal echo between Velabra in line 5 and labra in line 64. Ablatives absolute with siccus sandwich the consonant phrases torret sitis ora and tristia iura. ${ }^{19}$ Propertius' reworking of the Vergilian account places greater emphasis on the hydrological activity of Hercules than Vergil appears to have done. Propertius subsumes the hero's etiological function with that of his role as a transformer of environmental space. This is further suggested by 4.9.31, when Hercules is said to address the priestesses of the Bona Dea with a dry beard caked with dust (in siccam congesta puluere barbam). The emphasis on Hercules' mouth as drain, moreover, takes the body/landscape connection in Cacus and projects it onto Hercules, with Roman topography, water, and bodies all triangulated, with a focus on the mouth and throat.

Given the connotation of barathrum as a physical and corporeal drain, on the one hand, and the connection between drainage works and bodily excretion on the other, it seems quite likely that when Vergil refers to the cave of Cacus as a barathrum he is foreshadowing the image of the blood being drained from his throat (guttur). A particularly compelling reason to read the barathrumopening as a drain is Hercules' reputation as a so-called Master of Waters in the Greek landscape. ${ }^{20}$ Many myths exist of his role in opening up the sinkholes (barathra) that riddle the karstified landscapes of Arcadia. ${ }^{21}$ Throughout Greek literature, as Connors and Clendenon have shown, there is a pervasive

18 For speculation about the location of the grove of the Bona Dea, see L. Richardson, Propertius Elegies I-IV (Norman 1977), ad loc. 4.9.23-26.

19 See W.A. Camps, Propertius Elegies Book IV (Cambridge 1961), ad loc. and Richardson 1977, op. cit. (n. 18), ad loc.

$20 \quad$ See n. 2.

21 See, e.g., Paus. 8.14.2: "The Pheneations say these sinkholes are artificial and that Herakles

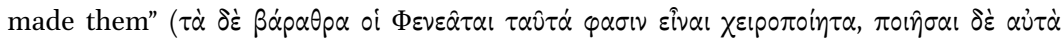

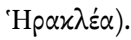


link between the subterranean channels and imaginings of the underworld. ${ }^{22}$ These associations, along with the bodily connotations of barathrum as well, are all captured in a passage of Catullus in a simile describing Laodamia's love as deeper than the karst sinkholes of Arcadia (107-112; 116-117):

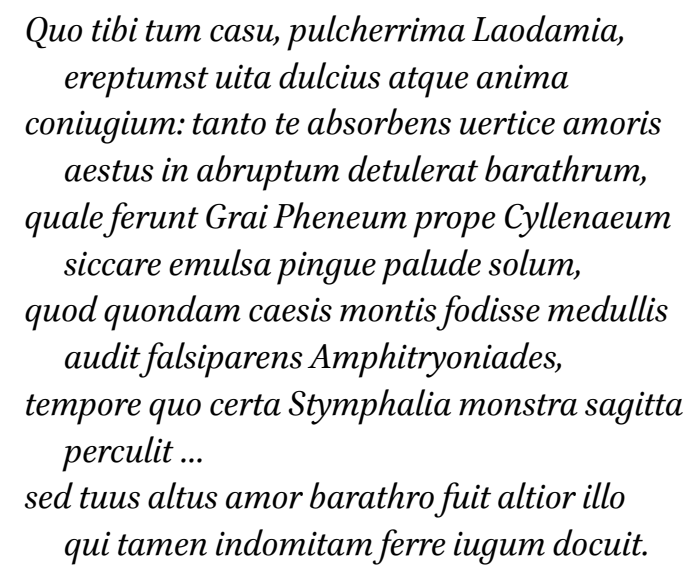

By what misfortune, most beautiful Laodamia, was your husband, who was dearer to you than life and soul, snatched away. The tide of love, swallowing you with such a whirlpool bore you into a steep sinkhole, the sort of [sinkhole] the Greeks say, when the rich swamp was dried up, drained the soil near Cyllenaean Pheneos, the sinkhole which the false-fathered son of Amphitryon is reputed to have once dug, with the mountain's marrow having been cut away, at the time when with sure arrow he destroyed the Stymphalian birds ... But your deep love, which learned to bear the yoke though untamed, was deeper than that sinkhole.

The drain to which Catullus refers was a canal that combined and channeled the Olbios and Aronaios - rivers that flowed in the valley where Pheneus was located - to a karst sinkhole through which the river flowed underground until it became the river Ladon flowing west towards the Ionian Sea. ${ }^{23}$

22 C. Connors and C. Clendenon, 'Mapping Tartaros: observation, inference, and belief in Ancient Greek and Roman accounts of karst terrain', ClAnt 35 (2016), 147-188.

23 Salowey 1994, op. cit. (n. 2) 87-88 explains these works and their connection to Hercules. He does not refer to the possibly more famous sinkhole through which he drained Lake Stymphalos into a channel that emerges to the east as the Eridanus. But the hydrology of the Stymphalos valley is nevertheless invoked with Catullus' chronological marker when he indicates that the canal at Pheneus was dug at the same time as the extermination of the Stymphalian birds. The battle with the Stymphalian birds (cf. also A.R. 2.1053-1067; 
There are numerous signs that this passage exerts influence on Vergil and Propertius. Most evident is the repetition of barathrum in the context of Hercules' labors and the use of the rare patronymic Amphitryoniades, which appears again in Propertius 4.9 - the only two appearances of this word in Latin elegiacs. Other verbal parallels between the passage and the proem to Elegy 4.9 further point to connections between Propertius and Catullus. As we have observed in Vergil and Propertius, Catullus' depiction of this scene triangulates topography, hydraulics, and bodies - both in its use of a hydraulic metaphor to describe Laodamia's emotions and in its anthropomorphization of the "marrow" (caesis ... medullis) of the limestone mountain. Still more importantly, Catullus specifies that the sinkhole opened near Cyllenaean Pheneus, which was, according to Vergil, the homeland of Evander, the Arcadian who settled in the site of Rome and who narrated the story of Hercules and Cacus to Aeneas. ${ }^{24}$ Therefore, it seems highly likely that this passage influenced both versions of the myth of Hercules and Cacus and thus informs our interpretation of the meaning of barathrum in Evander's tale.

Given all this, it is clear that both poems develop imagery of drainage of bodies and landscapes that are closely interconnected. However, explaining why this is the case is a more complex question. The most common suggestion made by scholars is that Hercules' drinking up the fountain functions as an etiology for the drying of the Velabrum. ${ }^{25}$ There are, however, several problems with this argument. For one, in late first-century Rome, the Velabrum still flooded periodically; Cassius Dio records four floods of the Tiber between 32 and 22 BCE, each which would have had some effect on the low-lying area. ${ }^{26}$ What is more, in neither account is the land flooded while Hercules is there. This is clear in Aeneid 8 since Aeneas meets Evander in a place that should have been inundated. Propertius, too, seems to say that the Velabrum is no longer flooded when Hercules arrives.

Str. 8.6.8; Apollod. Bib. 2.5.6; Paus. 8.22.4-6), if not as apparent as the defeat of the hydra or the struggle with the Alpheus, is also a hydrological labor.

24 Verg. Aen. 8.165.

25 Cf. Camps 1961, op. cit. (n. 19), ad loc. 4.9.19; Anderson 1964, op. cit. (n. 4), 11; Richardson 1977, op. cit. (n. 18), ad loc. 4.9.19; M. Janan, The Politics of Desire: Propertius Book IV (Berkeley 2001), 132, 145n1; Martinez 2009, op. cit. (n. 2) 211-212; Panoussi 2015, op. cit. (n. 7), 189. Although S. Heyworth, Cynthia: A Companion to the Text of Propertius (Oxford 2007), 487 notes that the pun sicco ... palato might "establish a contrast between the present Rome of chattering fountains and the dry Palatine of the past."

26 See D.C. 50.8.3 (32 BCE), 53.20.1 (27 BCE), 53.33.5 (23 BCE), and 54.1 (22 BCE). For a full list of floods of the Tiber in Roman history before $398 \mathrm{CE}$, see G. Aldrete, Floods of the Tiber in Ancient Rome (Baltimore 2007), 15. On the susceptibility of the Forum Boarium and Velabrum to floods, see Aldrete 2007, op. cit. (n. 26), 43-44. 
A different picture emerges if we read the episode in light of the waters flowing into and especially out of the city. Steep increases in the water supply and the increased need for drainage works that resulted from it were a core preoccupation of the Augustan regime. Indeed, one may read the Herculean drainage activities in the site of Rome as a commentary on this hydrological activity. First, it is necessary briefly to recap the Augustan hydrological program and the iconography associated with it. Between 33 BCE and 19 BCE, Marcus Agrippa commissioned two new aqueducts - an extension of the Aqua Tepula and the brand new Aqua Virgo - which most likely increased the amount of water flowing into the city by about $33 \%{ }^{27}$ Augustus apparently took pride in this, boasting that Agrippa's engineering genius had ensured the Romans would never perish from thirst. ${ }^{28}$ Besides, many other parts of Agrippa's building program were water-themed, perhaps associated with his naval victories and the corona navalis awarded to him by Augustus. Beginning with his aedileship in 33 BCE, he funded a suo privato a building program that radically transformed parts of the city. ${ }^{29}$ Notable here is his complex in the Campus Martius, which Paul Rehak called an "Augustan waterpark", and which contained a pool, an artificial canal, a basilica of Neptune, a portico decorated with paintings of the argonauts, and the Baths of Agrippa, which were the largest baths constructed in Rome up to that point. It was, finally, in $33 \mathrm{BCE}$ that he conducted the storied cleaning of the Cloaca Maxima. According to Pliny (nat. 36.28.104) and Dio (49.31), he even sailed through it in something of a triumphant plumber's katabasis.

That so many of his public works were water-related is perhaps not coincidental. Before he was an administrator and builder, Agrippa was a general

27 See A.T. Hodge, Roman Aqueducts and Water Supply (London 2002), 347 for the details.

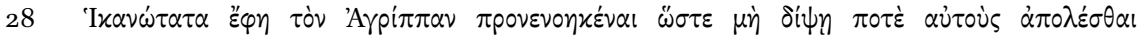
(D.C. 54.11.7); cf. also Suet. Aug. 42.

29 For ancient accounts of Agrippa's projects, cf. Str. 5.3.8; Frontin. aq. 1.9-10; Plin. nat. 36.104-108; 121; D.C. 49.43; 53.27.1-2; 54.11.7. Dionysius of Halicarnassus (3.27.3) wrote that Agrippa wanted to call the Pantheon the Augusteum. Scholarship on the various aspects of Agrippa's buildings in Rome is unsurprisingly voluminous, though only a handful of studies treat the program as a whole. See the admittedly dated F.W. Shipley, Agrippa's Building Activities in Rome (St. Louis 1933). P. Rehak and J. Young, Imperium and Cosmos: Augustus in the Northern Campus Martius (Madison 2006), 20-22 summarizes the works with bibliography. See also G. De Kleijn, 'The emperor and public works in the city of Rome', in L. de Blois, P. Erdkamp and O. Hekster (eds.), The representation and perception of Roman imperial power: proceedings of the Third Workshop of the International Network Impact of Empire (Roman Empire, c. 200 B.C.-A.D. 476) (Amsterdam 2003), 207-214, who gives evidence for how Agrippa's projects worked as propaganda. J.-M. Roddaz, Marcus Agrippa (Rome 1984), 252-298 is the most thorough survey of the project in the Campus Martius, even if it is a bit dated and theories about the Diribitorium and the Pantheon, in particular, have changed. 
whose greatest military victories were naval. His defeat of Sextus Pompey in 36 BCE earned him the corona navalis, a special honor created specially for him by Octavian. ${ }^{30}$ Notably, even this victory required waterworks, namely the Portus Julius in Cumae, an emergency harbor he had to create in order to train new troops to support Octavian, who was no match for Pompey. ${ }^{31}$ While this not strictly a 'waterwork' in the same sense as an aqueduct or stagnum, ancient evidence still associates it with water. Consider, especially, the representation of Agrippa and Augustus on the Vergilian Shield of Aeneas, respectively associated with fire and water. ${ }^{32}$ It is no wonder that later authors speculate that the purpose of the Porticus Argonautorum in the Campus Martius complex, so named because it featured paintings from that famous maiden voyage, was to commemorate Agrippa's naval victories. Numismatic evidence further corroborates the connection between Agrippa's public identity and the acquatic, as coins survive depicting him with a combined corona navalis and corona muralis, which had been awarded to the first soldier to scale the walls of the enemy. ${ }^{33}$ The designs on the crown's base resemble the entablature, featuring tritons, dolphins, and scallop shells, of what archaeologists call the Basilica of Neptune. The function of this building is still uncertain, but it was attached to the original Pantheon, and a small part of which still survives on the northern side of the current Pantheon.

Thus, representations of the control of water were an essential aspect of the Augustan/Agrippan imperial building program. ${ }^{34}$ Throughout the city, this hydrological imagery constituted a coherent theme linking temples, public pools, baths, aqueducts, and drains. Indeed, the twin control of fire and water was important enough to be represented at the very center of the Shield of

$30 \quad$ B. Bergmann, 'Die corona navalis: eine Sonderehrung für Agrippa', JdI 126 (2011), 77-106 provides an article-length summary of our evidence for the corona and its meaning.

31 This construction clearly captured Vergil's attention. He alludes to it at least twice portus Lucrinoque addita claustra (georg. 2.161); portus ... Averni (Aen. 5.813-815). Agrippa's naval activity is also present on the door of the temple at the beginning of georg. 3: atque hic undantem bello magnumque fluentem Nilum ac navali surgentis aere columnas (G. 3.2829). Cf. P. Fedeli, 'Agrippa e I letterati augusti', in Dipartimento di archeologia, filologia classica e loro tradizioni (ed.), Bimillenario di Agrippa (Genova 1990), 109-112; Y. Nadeau, 'Vergil's Sextus Pompeius Celaeno (and his defeat by Agrippa)', Latomus 66 (2007), 94-98, esp. 95; 97 .

32 See Verg. Aen. 8.678-684. On the elements of fire and water in Aen. 8, see Quint 2015, op. cit. (n. 1).

33 M. Grant, 'Agrippa's coins', in Dipartimento di archeologia, filologia classica e loro tradizioni 199o, op. cit. (n. 31), 9-19, here 12-13. See British Museum R.9242 for the coin type.

34 See also Purcell 1996 op. cit. (n. 2), 205-209 on the extent to which political and economic power shaped control of and discourse concerning Roman waterworks. 
Aeneas, just as Aeneid 8 as a whole is ringed by rivers submitting to Roman movement. Thus, when read in the context of this distinct increase in the volume of water pumped into Rome, the public arts and buildings that drew attention to that water, and the function of Agrippa as a quasi-Master of Waters, Hercules' gluttonous waterworks take on a new light. The hydrological goal of Hercules in Rome is no longer about clearing space for a settlement beside waters that already exist - it is also about controlling the entire world's waters and managing the thirst of the city and the constant influx of water into it. It is therefore appropriate that Hercules' proto-Actium on the Aventine would allude to waterworks flowing beneath the city and hill, as Romans repurpose the hero's Arcadian hydrological activity. The barathrum Caci in Vergil, and the mouth of Hercules in Propertius, both symbolize these hydrological ambitions as an aspect of empire, situating them within a broader symbolism of mythological and ideological drainage works in the Greco-Roman (and Italic) imaginary.

But Hercules' drains do not only channel the readers' minds forward to Rome's hydrological empire - they also channel them backward, to the natural waterways of Arcadia. Thus, these symbols, in different ways, also use the subterranean channel as a metaphor for the connection between the mythic past and the marble present. We have already seen how these effects read new events into the distant past of the Roman landscape and figure Evander's Arcadian nostalgia, since the location near Pheneus, Evander's Greek home in the Aeneid (8.165), gives the passage the effect of being a memory of Evander. It is as if Evander's Mediterranean is a landscape of imaginary limestone not unlike that of the porous land of Arcadia, the Homeric Lacedaemonia emphatically "hollow with hollows," in the words of the Odyssey. ${ }^{35}$ In the hydraulic context of Augustan Rome, this connects these ancient, pristine spaces to the brick and marble channels of the modern city. It, therefore, establishes a kind of hydrological continuity that mingles present and past in the subterranean channels of memory, figured as a subterranean waterway.

Nevertheless, these episodes also suggest anxiety about Roman waterworks. In both poems, water is present insofar as it is absent. Cacus, first encountered heaving fire and smoke, has the blood drained dry out of his throat. In Propertius 4.9, a parched hero exhausting a sacred spring swiftly replaces the mirage of watery abundance that opens the elegy. Thus, rather than working to regulate an abundance of water, Hercules' drainage works seem to be, as it were, superfluous, functioning to drain spaces that are already dry and causing

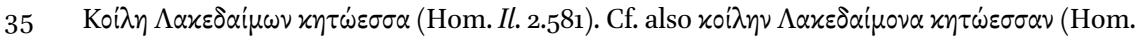
Od. 4.1). 
desiccation both in the landscape and in the bodies that move through it. This paradox is perhaps further reinforced by the fact that it is Cacus - the volcanic son of Vulcan associated by Vergil more with fire than any other element - is a symbol for that which Hercules as Roman plumber must overcome. ${ }^{36}$ Thus, rather than serving only to prefigure the triumphal accomplishments of the Augustan/Agrippan curatio aquarum, the hydrological exploits of Hercules also seem to evidence anxiety about Roman thirst and water scarcity as a practical, ethical, or ideological problem. Empires, after all, are thirsty beings, and their barathra can be bottomless.

Vergil's emphasis on continuity and discontinuity in the landscape rather than Hercules' domination or 'civilization' of it offers an alternative model for reading Roman attitudes towards their relationship with hydrological environments. As Purcell and others have shown, encounters with and control of waters were important for Roman conceptualization of space, as is shown, for example, by the outsized influence that hydrological features in the environment have on Roman toponomy. For Purcell, the Roman "romance of drainage" is a story of control over the environment, and the enlistment of the "heroes of drainage" like Hercules from the Greek world function to connect Roman environmental management to that of the Greek polis. ${ }^{37}$ But the environmental revelation that comes with the death of Cacus is not new land reclaimed beneath receded water. Instead, it is fixated on the cavities through which water disappears, and the losses and connectivities created by them. It is in this way neither straightforward praise nor censure of the new hydrological regime. Rather, perhaps, Vergil deploys the physical imagery of drainage works as a metaphor for the kinds of ambiguity towards Augustus with which he is so often associated.

To conclude, by ending their accounts of the battle between Hercules and Cacus with imagery of bodies draining or being drained of fluid, both Vergil and Propertius suggest that Hercules' associations with the creation of new waterways and subterranean channels are salient to the episode. The connotations of the word barathrum that Vergil uses in reference to the exposed cave of Cacus further confirm this. By importing Hercules as Master of Waters into a Roman context, these two poets both incorporate into the episode commentary on the

36 On the volcanic imagery associated with Cacus, see A. Scarth, "The volcanic inspiration of some images in the Aeneid', CW 93 (2000), 591-6o5. Here one might compare Verg. Aen. 3.694-696, which imagines the Alpheus River running under the Ionian Sea, connecting Arcadia with Sicily, and mixing Arethusa with Sicilian waters. Here too there is a confluence of hydrological and volcanic veins materializing a connection between Greece and Italy.

Purcell 1996, op. cit. (n. 2), 205. 
ethics and symbolism of Rome's consumption of water. On the one hand, this allows them to connect Arcadian and Roman waterworks, bridging time and space, karst and cloaca. On the other hand, Hercules' waterworks also seem implicitly to criticize the excesses of Rome's water consumption. ${ }^{38}$

38 Special thanks to David Levene, Alessandro Barchiesi, Michael Peachin, Genevieve Gessert, Jordan Rogers, and Ben Nikota for reading drafts of this paper and offering generous feedback, and to the participants in the 2019 Impact of Empire Network conference in Mainz for the stimulating discussion. 